\title{
A poesia de Xavier Frias Conde
}

\author{
ANDRÉS José PociÑA LÓPEZ \\ Universidade de Extremadura \\ apocina@unex.es
}

Recibido: julio de 2012 Aceptado: septiembre de 2012

\begin{abstract}
Resumo: A poesia de Xavier Frias Conde é uma coabitação do rural e do urbano, do passado e do presente, do amor e do desamor, é um poeta dos binómios, vistos eles como o as duas faces duma mesma realidade. É um poeta castelhano de origens eo-naviegos que adoptou o galego como língua de expressão
\end{abstract}

Palavras clave: poesia, eo-naviego, Grupo Bilbao

Resumen: La poesía de Xavier Frías Conde supone la convivencia de lo rural y lo urbano, el pasado y el futuro, del amor y del desamor. Es un poeta de los binomios, aunque vividos como las dos caras de una misma realidad. Es un poeta castellano de orígenes eonaviegos que adoptó el gallego como lengua de expresión

Palabras clave: poesía, eonaviego, Grupo Bilbao

Quero começar agradecendo o convite a participar neste simpósio sobre letras galegas no Dia das Letras Galegas, num lugar como Madrid, relativamente afastado das terras galegas - já que não sentimentalmente, como se está a demonstrar neste evento, pelo menos sim geograficamente: há uma N-VI de permeio, ou uma linha de caminhos de ferro para quem gostar de caminhar por sobre o ferro. Vou falar sobre um indivíduo chamado Xavier Frias Conde e sobre a poesia que este tem escrito, e continua a escrever, em galego. Xavier Frias Conde é galego de Extramuros e, para mais sinais, galego de terra adentro... E bem adentro! Galego de Béjar, província de Salamanca. Béjar, ducado antigo de renome cervantino e brasão de abelhas, como o brasão do Império de Bonaparte, como o brasão dos Barberini, como o símbolo da imortalidade no Antigo Egito. A abelha é símbolo antigo e fundamental. Dat rosa mel apibus, «a rosa dá mel às abelhas», proclama a divisa da Irmandade Rosa-Cruz. E numa vila de brasão com três abelhas nasceu Xavier, nas Terras Frias que outrora pertence- 
ram a um Conde, mais adiante elevado à dignidade de duque. Béjar, terra onde o galego não se deixa ouvir, talvez não mais do que no zoar do vento nos carvalhos e nos castanheiros, as árvores galegas por excelência, que tão floridamente medram também naquelas serras da Galiza tão interior de fora da Galiza. E o mar? Mar não há, em Béjar. Mas o galego de Frias (Conde) procede dum mar nevoento, proceloso, o Cantábrico, duma terra nem tão interior nem tão de fora da terra galega, mas sim o suficiente para ter merecido que alguém o declarasse persona non grata, a Xavier, a uma pessoa sempre tão grata como Xavier Frias.

Chamemo-la Terra d'Entre Eu e Návia, reavivando um costume de ressonâncias antigas no nomenclátor provincial mais antigo, real ou imaginário, dum mítico e sonhado Reino da Galiza - Portugal- Astúrias (por que não Leão?), com províncias de sonorosos nomes de rios: Entre Douro e Minho, Entre Tejo e Odiana (melhor do que Alentejo), Entre Tambre e Ulha, Entre Neira e Sárria, Entre Cabe e Sil... Porque não, também Entre Eu e Návia, terra de galego peculiar de fora do galego (para alguns, fora do mundo, fora do seu direito a ser galego). Um galego (no sentido figurado, pois Xavier nunca se tem reconhecido, nem se reconhece, como galego, mas antes como «habitante da língua galega») do Extremo Oriente, procedente não já da Galiza do Galego Oriental, mas da terra do Galego Oriental ao Oriente da Galiza, um pouco como aquele Fernando Pessoa/ Álvaro de Campos, que procurava «um Oriente ao oriente do Oriente» 1

Falo de um galego do Oriente, do Oriente extremo-oriental galiciano, fora dos limites respeitados, impostos. Falo de um galego da Galiza Irredenta, nem por isso menos Galiza que a Galiza dos mapas escolares. Quem nos dera podermos erguer algum dia o Mapa de Fontán, tão idolatrado pelo mestre dos mestres, Dom Ramón Otero Pedrayo, quem nos dera poder erguê-lo à categoria de monumento nacional (não sabemos de que nação, nem falta que faz!) Falo de um galego de Béjar, de Madrid, de Praga e de Lisboa, de um amigo das aldeias (A Aldea é o nome do seu último livro publicado, ainda que não de versos, mas de narrativas: Frias Conde, 2011), da sua própria aldeia eo-naviega e das aldeias de todo o mundo, daquelas aldeias tão aldeias que florescem naquela Terra de Miranda, portuguesa e ao mesmo tempo tão asturo-leonesa de fora das Astúrias e do Reino de Leão. Falo eu, que sou galego nado em Salamanca (isso sim, na capital provincial!) e procedente de linhagens galegas de interior, de terras orientais, de falas orientais, tão desprezadas, às vezes, pelo galego que se ergueu em norma literária, como o galego extremo-oriental de Xavier. Falo como vergôntea de um tronco oriental de terras de carvalhos e de castanheiros, sulcada por um Caminho Francês que nos santificou de mãos de um Aymerico Picaud, falo, pois, de um galego de fora da Galiza, que pertence a um grupo de poetas galegos residentes em Madrid e que ostenta o nome de Grupo Bilbao. Difícil é ser tão cosmopolita: Galego, Madrid, Bilbao². Pois sim senhor. É de um cosmopolita que vos venho falar. E já me esquecia das

1 No poema Opiário, Campos (Pessoa), 1991: 135.

2 Não empece que o nome do grupo Bilbao faça referência, em realidade, ao nome duma praça, ou rotunda («glorieta») na que se situa o Café Comercial, «sede» das tertúlias; é essa «glorieta» que tem dado o seu nome ao grupo Bilbao. Mesmo assim, o prosaísmo do real não empece a lírica do «cosmopolitismo»: Bilbao é Bilbao, em que mais não seja, pelo poder evocador do nome. Seja como for, «se non è vero, è ben trovato». 
abelhas! As abelhas do brasão de Béjar: o símbolo da imortalidade dos Egípcios. Frias Conde, esse galego oriental de fora dos limites extremo-orientais, foi procurar os segredos, da imortalidade ou de outras sabedorias, a Mênfis, nas areias do Deserto Egípcio, nessa Axarquia ${ }^{3}$ que não é a Ajarquía de Málaga, mas a Axarquia dos Faraós, perdida nas areias do deserto, onde aninha o medo, mas também a sensualidade oriental, extremo-oriental (eo-naviega, portanto). Deserto de areia, seca, secura, sequidade, mornez do sol. Ardor do sol. País de abelhas imortais, à procura da frol, do sumo, do alimento. País de corpos desejosos, de avidez, de corpos desejados, de ausências, de procuras, de lembranças, de procuras, de saudades, de procuras, de senhardade, de procuras. Será a procura, justamente, o segredo da imortalidade da abelha?

A abelha dos Faraós. Talvez procure, ela, aquele paraíso verde de Frias, Azul e Terra (Frias Conde 2000), azul-verde, verde de erva, azul de mar, de Mar Cantábrico, Mar de Fora, mar da dúvida, mar das lembranças: infância, memória, brêtemas, enfim. Mar, enfim, impertinente mar da angústia, impenitente mar da solidão, mar rouco e bravio, mar bruante, mar da incompreensão. Se tivesse de escolher uma soa palavra que em si pudesse conter, e definir de um modo abrangente, a quinta-essência da poesia de Xavier, escolheria esta: PROCURA. Poesia de procura, poesia de busca. Poesia de inquietude. Poesia de caminhar todos os caminhos, sem sabermos para onde nos conduzem. A procura na poesia de Xavier Frias: procura do quê? Singelamente, procura de todas aquelas cousas que nos tolhem o sono aos mortais: o amor, as respostas a todas as nossas inquietações, a felicidade, os longes inatingíveis... Poesia, sim, poesia da procura. Poesia da abelha que procura froles no deserto. Mas será que a abelha encontra a sua imortalidade na procura da frol na imensidade do deserto? Dat rosa mel apibus: é a rosa que dá o mel às abelhas. A rosa, no caso de Xavier, é, reiteradamente, o corpo feminino. Que melhor fonte de mel? (mas prefiro abster-me de comparações procazes). Mel da paisagem, paisagem que se funde com o corpo feminino também: «teis a pel de herba», impecável verso de Azul e Terra (Frias Conde 2000: 20), que nos demonstra como, num único verso, pode caber toda uma conceição do mundo.

Procura através de todo o mundo, da Europa toda, através de «tutte le Città», «de todas as Cidades», «de todas las Ciudades» (Frias Conde 2010). Procura através de todas as línguas, conhecidas e desconhecidas, grandes ou pequenas, marginadas, marginalizadas ou, pelo contrário, triunfantes. Procura no Mar de Letras, como os navegantes silenciosos da Cabala, tantas vezes desorientados nas suas singraduras pela Torah. Ausências e presenças. Que outra cousa é, de feito, $O$ Canto de Nedara (Frias Conde 2001), senom o Canto da Procura de Nedara?

Azul e Terra. O livrinho de poemas Azul e Terra começa no mundo de hoje, nos barulhos urbanos, no mundo citadino, opressivo, reteso e complicado, «tempo de voces como puños», tempo dominado por aqueles que ostentam «bandeiras» e «naciois», «letras entre teas de araña e nomes/ tan propios como recónditos/ a fe-

3 É portanto, Axarquia, que se titula um dos seus livros de versos mais sugestivos: Frias Conde (2002). O texto a que faço referência, mais concretamente, é o poema 3 (incipit «consultei o oráculo de Mênfis», onde o poeta declara que foi consultar esse oráculo, no meio das areias do deserto. p. 7. 
deren tras dos sous beizos» (Frias Conde 2000: 13). Porém, e se bem é certo que «hai nubres no tou sorriso», pede-se a alguém: «ergue no alento,/ cala/ e deixa salir as túas fadas» (Frias Conde 2000: 14). Petiçom, esconjuro, necessários para começar a andaina. E a procura começa.

Mais uma vez o erotismo, «percorro cun dido/ o contorno dos tous beizos/ miúdos», «quero afundirte na mía pel,/ que señas brisa de alentos.../ Tou nome/ tan nidio/ explora meus silencios» (Frias Conde 2000: 17).

E esse mundo verde a contrastar co mundo «sério», buliçoso, sem ideais. Esse mundo verde que está aí, à espera, mas que é rejeitado, esquecido de todos: «era tempo de pantasmas [...] De nada valiron beiras de mar,/ de nada valiu o sangue verde/ nin a voz dos freixos/ nin a color das fontás» (Frias Conde 2000: 18). Por outro lado, a volta do passado, provavelmente mais mítico do que real: «escuitou canciois do escuro,/ lambeu carreiros do pasado» (Frias Conde 2000: 26). A sensualidade, a sensualidade sempre, mesmo como via para a Eternidade: «sei/ que tous beizos/ me pertencen/ no máis eterno» (Frias Conde 2000: 27). Às vezes parecem ressoar as cantigas velhas: «penso que a lúa/ de día dorme nos tous beizos./ Outramente/ non me explico/ porque tous bicos/ tanto brillan» (Frias Conde 2000: 36).

Apesar do «exílio», da vida longe da aldeia, longe da Origem, da Mai Telúrica, sabe-se que a aldeia ainda existe, e isso conforta; mas, ao mesmo tempo, também punge, por não se poder estar lá:

\author{
Sentar a pensar \\ que aló tan lonxe \\ a pesar da mía ausencia \\ a aldea late, \\ el río corre, \\ a festa apigarza. \\ Sentar a sentir \\ un salgueiro que me chama, \\ un camposanto que guarda camíos, \\ un vale que me boutiza \\ e eu tan lonxe (Frias Conde 2000: 45).
}

A procura, pois, sempre a procura. Mas sempre também a lembrança, señardade feita inxusticia/ remembranza,/ remembranza,/ remembranza/ sempre perenne como berro incesante» (Frias Conde 2000: 47). E sempre a procura, a saudade de «un nome de aldea/ que pon color aos meus ollos» (Frias Conde 2000: 49). Que, no fundo, é sempre uma «procura del eterno»: mas esse eterno acha-se sempre, segundo a lógica de Xavier, logicamente, no «tu»: «estou/ boca aberta,/ beizos solertes/á procura del eterno.../ tu» (de Lar de Lúa: Frias Conde, 2003: 8). Procura, sempre procura.

Procurar através das normativas e das desnormativas ortográficas e heterográficas, galego-asturianas, galego-portuguesas, através dos idiomas, das suas sincronias, anacronias e ucronias, dos seus encontros e desencontros. Procurar talvez a língua verdadeira, a do miolo, a língua do Paraíso, a língua das Origens, a 
língua, enfim, do berce: não do berce autêntico, claro, mas do berce sonhado, ideal, fantasioso, mítico, que é o que de verdade importa. Vou contar-vos um conto ${ }^{4}$.

Outro Xavier que não o Frias Conde, São Francisco de Xavier, profeta, pregador, evangelizador e apóstolo do Oriente, chegou a aprender ao longo da sua vida até nove idiomas: sendo o seu idioma materno o êuscaro, aprendeu castelhano, francês, latim, italiano, português, tâmul (ou tamil), malaio e japonês ${ }^{5}$. Nos últimos tempos na missão só falava, além do latim eclesiástico, português e japonês, línguas da pregação jesuítica no Japão; talvez também um pouco de castelhano com os seus compatriotas. Teria esquecido para sempre o idioma dos seus pais?

Estando já no leito da morte, eis que o santo começa a falar, entre delírios, numa língua incompreensível, nunca ouvida pelos frades que o acompanham. Medo e angústia: estará a ser tentado pelo Demo? Os especialistas chamados declaram sem hesitar não ser aquela língua que fala nem tamil, nem árabe, nem drávida, nem nenhuma outra língua conhecida. Será aramaico? Também não. Eis porém que um frade biscainho, também da missão, acerta a abeirar-se, também el, do leito da agonia e, perante o pasmo de todo o mundo, começa a parolar co apóstolo, tranquilamente, ambos no mesmo idioma. $\mathrm{O}$ frade navarro estava a falar vasconço, a língua do seu amanhecer à Vida e ao Reino deste Mundo.

Quiçais o termo da procura deste inquieto andamento do Xavier (do Xavier do Extremo Oriente japonês, como também do Xavier desse Extremo Oriente d'Entre Eu e Návia) seja justamente essa língua da infância (não da infância real, repito, mas da infância mítica, arquetípica, essencial) e, em simultâneo, de todo aquilo que nessa língua se pode exprimir: a procura de todas as vivências, sentimentos e ideias que cabem nessa língua universal e primigénia, que ninguém conhece nem decifra. Essa língua (/idioma) que por vezes se pode surpreender, se quadra, nas línguas (/órgão corporal, bucal) das mulheres, nas línguas que escorregam pela pele como a «língua» duma abelha à procura do néctar numa frol - talvez aquela rosa que dat mel apibus. Daí a recorrência e protagonismo do erotismo na obra de Xavier Frias, o Conde da Axarquia, gostador de cafés e chocolates quentes... talvez também abelha gorentadora de meles, abelha como aquelas que figuram no brasão da Muy Leal Villa de Béjar.

\section{EPÍLOGO}

Como círculo que se fecha, como serpe ouróboros («que se morde a cauda»), símbolo caro aos alquimistas, não raro a vida é um ciclo que nos acaba levando às origens, ao berce, nos dias derradeiros do nosso passeio, mais curto ou mais longo, por este mundo. É o caso de Francisco de Xavier — o seu retorno à

$4 \mathrm{O}$ «conto» seguinte não é inteiramente da nossa lavra: baseia-se, novelando-a, numa anedota que se conta sobre o Santo, metade verídica, metade lendária. Sobre o feito (controverso) de Xavier ter voltado ao uso da língua «biscainha» nos seus derradeiros dias, cfr. Alonso Romo 2000: 62-65.

5 Segundo o cronista da Ordem, Schurhammer, «Xaverius varias linguas in decursu vitae didicit: biscainam, hispanam, gallicam, latinam, italicam, lusitanam, tamulicam, malaicam, japonicam» (apud Alonso Romo 2000: 59). 
língua (quem sabe se ao mundo, às paisagens) da infância. Um outro caso, também mui belo e interessante, foi comentado no debate público com que se encerrou esta minha digressão. Quero lembrá-lo, por ser belo e por me ter sido pedido delicadamente que o adjuntasse nesta versão escrita da minha conferência, que se prepara para figurar nas Actas do simpósio. Foi Vicente Araguas, nada menos, quem contou o caso, que se refere ao seu pai, D. Antonio Araguas Neira, capitão de navio da Armada de Guerra Espanhola. Homem do exército, não discutidor da ordem (ditatorial, ferrenha, totalitária) do regime franquista, o capitão Araguas Neira negou-se sempre rotundamente a falar «esse dialecto do espanhol» que se chama galego. Negou-se, sim, apesar de ser essa a Língua do seu contexto familiar e materno, a Língua da terra em que nasceu. Chegava mesmo a repreender (assim nolo confessou Vicente na sua alocução pública) ao filho por escrever nesse «dialecto». Assim e todo, nos dias de hoje, sendo o capitão de navio já um homem ancião, de bastante mais de oitenta anos, dando já sinais de cansaço vital e intelectual, eis que o homem volve cada vez mais «ao lar da infância», a falar cada vez mais amiúde o «dialecto» dos seus paisanos, a Língua da terra que o viu nascer. Volta às origens, regressa, nos derradeiros anos da vida, à língua que falava nos primeiros. Como no caso do apóstolo navarro. Como no caso, seguro, de tantos outros mortais. E portanto, valerá a pena afastar-se, tanto como o fazemos os doudos seres humanos, do mundo da infância, da ingenuidade do começo do mundo, do espaço sorridente da Natureza, os verdeceres dos prados, os avessedos das carvalheiras? Azul e Terra. Apenas duas palavras. Mas nelas quiçais se resuma um mundo.

\section{BIBLIOGRAFIA}

Alonso Romo, E. J. (2000) Los Escritos Portugueses de San Francisco Javier, Braga, Universidade do Minho.

Campos, A. de (=Pessoa, F.) (1991) Poesias de Álvaro de Campos. Lisboa, Edições Ática.

Frias Conde, F. X. (2002) Axarquia (Ǎ̌šarqiya), Madrid, Arte Tripharia

Frias Conde, F. X. (2000) Azul e Terra. Poesia eonaviega (1997-1999), Madrid, Acef.

Frias Conde, F. X. (2001) Canto de Nedara, Madrid, Arte Tripharia

Frias Conde, F. X. (2001) Lar de Lúa, Biblioteca Virtual Eonaviega.

Frias Conde, F. X. (2010) Città/ Cidades/Ciudades. Pontevedra, El Taller del Poeta.

Frias Conde, F. X. (2011) A Aldea. Cando as néboas dos carreiros contan historias, Santiago de Compostela, Urco Editora. 